\title{
Analisa Strategi E-Marketing Dinas Koperasi UKM Kota Medan terhadap UKM Binaan di Tengah Pandemi Covid-19 Tahun 2020
}

\section{E-Marketing Strategy Analysis of Koperasi Department Medan City UKM To UKM Development In Middle of the 2020 Covid-19 Pandemic}

\author{
Ida Lindiawati' ${ }^{1}$, R. Hamdani Harahap ${ }^{2}$, \& Siti Mardiana ${ }^{3}$ \\ 1Program Studi Magister Administrasi Publik, Universitas Medan Area, Indonesia \\ ${ }^{2}$ Fakultas Ilmu Sosial dan Politik, Universitas Sumatera Utara, Indonesia \\ ${ }^{3}$ Fakultas Pertanian, Universitas Medan Area, Indonesia
}

Diterima: 09 Juni 2021; Disetujui: 15 Desember 2021; Dipublish: 01 Januari 2022

\begin{abstract}
Abstrak
Tujuan penelitian ini untuk: 1) Menganalisis dan mamaparkan efektivitas strategi pemasaran online berbasis internet produk UKM, 2) Menganalisis dan memaparkan implementasi strategi pemasaran online berbasis internet produk UKM, 3) Menganalisis dan memaparkan faktor pendukung keberhasilan strategi pemasaran online berbasis internet produk UKM, dan 4) Menganalisis dan memaparkan faktor penghambat keberhasilan strategi pemasaran online berbasis internet produk UKM. Hasil penelitian menunjukkan bahwa efektivitas strategi pemasaran online berbasis internet produk UKM Binaan Dinas Koperasi Kota Medan masih kurang maksimal. Faktor penyebab dari hal itu dikarenakan keterbatasan anggaran promosi yang dimiliki oleh Dinas Koperasi UKM Kota Medan pada tahun 2020 juga dengan kebijakan refocusing. Implementasi strategi pemasaran online berbasis internet produk UKM binaan Dinas Koperasi UKM Kota Medan tahun 2020 di tengah masa pandemi covid-19 diterapkan dan patuh pada azaz koordinasi, gagasan kerja sama melalui bank BRI guna membuka kemudahan akses kredit, kerja sama dengan usaha-usaha online membangun market place digital dengan Grabfood, penyediaan market place di Bukalapak. Hambatan jarak pelatihan dan minat yang tinggi untuk mengikuti pelatihan terlihat cukup dominan.
\end{abstract}

Kata Kunci: Analisa Strategi E-Marketing; Pandemi Covid-19

\begin{abstract}
The objectives of this study are to: 1) Analyze and explain the effectiveness of internet-based online marketing strategies for SME products, 2) Analyze and explain the implementation of internet-based online marketing strategies for SME products, 3) Analyze and describe the supporting factors for the success of internet-based online marketing strategies for SME products, and 4) Analyze and describe the factors inhibiting the success of the internet-based online marketing strategy for SME products. The results showed that the effectiveness of the internet-based online marketing strategy of the SME products assisted by the Medan City Cooperative Office was still not optimal. The causative factor for this is due to the limited promotional budget owned by the Medan City UKM Cooperative Office in 2020 as well as the refocusing policy. The implementation of an internet-based online marketing strategy for SME products guided by the Medan City UKM Cooperative Office in 2020 in the midst of the Covid-19 pandemic was implemented and complied with the principles of coordination, the idea of cooperation through BRI banks to open easy access to credit, cooperation with online businesses to build digital market place with Grabfood, providing a market place at Bukalapak. Barriers to training distance and high interest in participating in training were seen to be quite dominant. Keywords: E-Marketing Strategy Analysis; Covid-19 Pandemic
\end{abstract}

How to cite: lindiawati, I., Harahap, H. \& Mardiana, S. (2022). Analisa Strategi E-Marketing Dinas Koperasi UKM Kota Medan Terhadap UKM Binaan Di Tengah Pandemi Covid-19 Tahun 2020. PERSPEKTIF, 11 (1): 140-150

*Corresponding author:

ISSN 2085-0328 (Print)

E-mail: sitimardiana@staff.uma.ac.id ISSN 2541-5913 (online) 


\section{PENDAHULUAN}

Ekonomi

kerakyatan

merupakan

kesatuan utuh dari pertemuan angka penjualan dan pembelian yang berlandaskan pada daya beli masyarakat. Koperasi dan Usaha Mikro Kecil dan Menengah (UMKM), menjadi penggerak ekonomi rakyat pada sistem ekonomi nasional. Dilakukan secara mandiri melalui pengelolaan sumberdaya ekonomi yang dikuasainya. Jumlah Usaha Mikro Kecil dan Menengah (UMKM) di Indonesia terus bertambah setiap tahun. Di tahun 2018 ini saja, jumlah pengusaha UMKM diprediksi mencapai 58,97 juta orang. Bahkan, angka ini diprediksi terus meningkat di tahun 2019. Penyerapan tenaga kerja hingga peningkatan produk domestik bruto yang cukup besar merupakan sumbangan penting bagi sektor ekonomi di Indonesia, yaitu mencapai 60,34 persen di tahun 2018. Di tahun 2020, jumlah pelaku UMKM di Indonesia menjadi 59,2 juta orang (Yuliani, Ayu, Kemenkop UKM: 3,79 Juta UMKM Sudah Go Online, https://kominfo.go.id/ 17/11/2017, diakses kembali pada 5/8/2020).

Kebijakan pemerintah menunjukkan keberpihakan pada usaha UMKM. Menerapkan langkah tepat guna membangkitkan perekonomian dengan fokus kebijakan yang dilakukan guna memperbaiki UMKM dapat lebih optimal, diantaranya dengan: 1) Memperbesar porsi UMKM di sektor produksi, 2) Memperbanyak pelatihan untuk branding dan packing, 3) Membuka akses pasar, business matching, 4) mendorong adanya platform $e$ commerce, dan 5) Meningkatkan akses permodalan untuk UMKM. Sejumlah fokus tersebut diimplementasikan dalam beberapa kebijakan dan program yang sudah dan akan berlaku. Kebijakan atau program yang dapat menjadi momentum akselerasi UMKM di tahun 2020, seperti penurunan tarif PPh Final UMKM dari $1 \%$ menjadi $0,5 \%$ sejak tahun 2018 . Upaya pemerintah menurunkan pajak UMKM menjadi 0,5 persen, agar geliat bisnis UMKM semakin berkembang pesat.

Permasalahan Usaha Kecil Menengah (UKM) yang sering luput dari perhatian pengusaha UKM adalah branding (10 Permasalahan UKM dan Cara Mudah Mengatasinya, https://interactive.co.id/ 08 Februari 2019, diakses kembali pada 5 Agustus 2020). Belum banyak pelaku UKM yang sadar akan pentingnya branding bagi produk dan juga usahanya. Kebanyakan pelaku UKM hanya fokus menjual. Tidak berpikir bagaimana kualitas merk dari produknya. Padahal, konsumen membeli karena mengingat merk tertentu pada pengalaman pribadi atau orang lain disekitar mereka, dengan jaminan kualitas dan kepuasan penggunaan.

Menjaga kualitas branding sangatlah penting dalam upaya membesarkan bisnis UKM. Kualitas branding yang baik pada suatu produk akan lebih mudah diingat khalayak. Sehingga peluang terjadinya penjualan pun semakin besar. Cara Mengatasi: Untuk meningkatkan kualitas branding produk UKM Anda, langkah pertama yang harus Anda lakukan adalah melakukan analisa SWOT (Strengths, Weaknesses Opportunities, Threats) terhadap produk. Analisa tersebut adalah kekuatan, kelemahan, serta peluang dan ancaman terhadap produk Anda.

Usaha Kecil Menengah (UKM) sebagai usaha ekonomi produktif, berdiri sendiri, usaha orang perorangan atau badan usaha yang bukan merupakan anak perusahaan yang dimiliki, dikuasai atau menjadi bagian baik langsung maupun tidak langsung dari usaha menengah atau usaha besar yang memenuhi kriteria usaha kecil. Pada praktiknya, UKM juga diatur oleh beberapa peraturan seperti Surat Edaran Bank Indonesia No. 26/I/KK tanggal 29 Mei 1993 perihal Kredit Usaha Kecil (KUK) yakni usaha yang memiliki total asset Rp. 600 juta tidak termasuk tanah atau rumah yang ditempati. Tidak boleh lebih dari itu. Sedangkan menurut Departemen Perindustrian dan Perdagangan, pengusaha kecil dan menengah adalah kelompok industri modern, industri tradisional dan industri kerajinan yang mempunyai investasi, modal untuk mesinmesin dengan resiko investasi modal/tenaga kerja Rp. 625 juta ke bawah dan usahanya harus dimiliki warga negara Indonesia.

Permasalahan nyata UMKM yang paling menonjol adalah rendahnya produktivitas, rendahnya nilai tambah dan rendahnya kualitas produk. Diakui bahwa UMKM menjadi lapangan kerja bagi sebagian besar pekerja Indonesia, akan tetapi cenderung dengan strategi pemasaran minimal. Kontribusi dalam pengeluaran nasional untuk UMKM dinilai rendah. Kondisi ini menerangkan bahwa produktivitas sektor mikro dan kecil masih rendah dibandingkan dengan usaha yang lebih besar. 
Usaha UMKM untuk menghasilkan laba dilakukan dalam pada tiga sektor usaha, yakni: 1) Usaha manufaktur (manufacturing business), 2) Usaha dagang (merchandishing business), dan 3) Usaha jasa (service business). Setelah barang diproduksi, sektor jasa memilih produk tertentu untuk melayani konsumen, permasalahan UMKM selanjutnya terletak pada masalah pendistribusian. Selama ini banyak pelaku UMKM kekurangan channel dalam mendistribusikan produknya. Kebanyakan hanya fokus mendistribusikan barang kepada beberapa kolega dan pengepul yang dikenalnya saja. Tentu cara pemasaran seperti ini masih sangat sederhana dan jangkauannya belum terlalu luas.

Strategi pemasaran dilakukan berbedabeda dalam upaya mengatasi masalah-masalah di UMKM. Strategi tidak hanya berupa rencana, akan tetapi disatukan dengan upaya mengikat bagian-bagian secara keseluruhan guna mensukseskan pemasaran barang atau jasa. Bertujuan untuk menumbuhkan perhatian, juga keputusan untuk membeli atau menggunakan jasa produksi UMKM. Terkait dengan itu, pemasaran menunjuk pada konsep menyeluruh, meliputi kegiatan penjualan, seni dagang (merchandising) dan distribusi. Masingmasing istilah ini menunjukkan satu bagianbagian, satu kegiatan dari seluruh sistem pemasaran (Abdullah, Tantri, 2015: 3). Menjadi rencana menyeluruh, sebagai langkah pemasaran dengan perencanaan bisnis, terdiri dari kegiatan: 1) Menetapkan pasar sasaran, 2) Menentukan posisi produk, 3) Menetapkan sasaran penjualan, dan 4) Menetapkan sumber daya yang diperlukan untuk mencapainya. Unit kerja dalam bagian-bagian di dalam kegiatan penjualan menjadi pendukung bagi rencana pemasaran. Bagian keuangan, pembelian, produksi, penyaluran dan personalia, untuk menjamin dukungan bagi rencana pemasaran dengan kecukupan uang, material, mesin dan personalia.

Sumatera Utara tahun 2019 memiliki 2,8 juta UMKM, yang tercatat di Dinas Koperasi UKM Provinsi Sumatera Utara, hanya 380 ribu, hal ini menunjukkan lemahnya pendataan terhadap sektor UMKM yang telah memberikan kontribusi signifikan dalam pertumbuhan ekonomi di Sumatera Utara. Tantangan untuk dapat membuat database UMKM Sumatera dengan akurat. Data yang akurat akan menentukan kebijakan yang akan dikeluarkan (Wiwiek, 2019).

Keberpihakan pemerintah daerah merupakan wujud nyata tentang pengakuan keberadaan UMKM di tengah masyarakat. Kegiatan ekonomi yang berskala mikro, kecil dan menengah dihitung berdasarkan pada nilai asset usaha dan keuntungan yang diperoleh pada setiap tahunnya. Langsung berhadapan dengan konsumen ditengah kondisi ketidakmenentuan ekonomi saat ini akibat pandemi virus corona-19 yang juga terdampak terhadap sektor UMKM di Kota Medan.

Selain itu, keberpihakan konsumen terhadap produk UMKM juga tidak bisa diabaikan. Konsumen penentu keberhasilan dari strategi pemasaran yang dilakukan sektor UMKM. Hak konsumen mendapatkan informasi dari ragam sumber informasi, diolah dan menjadi penentu pengambilan keputusan pembelian dan mengkonsumsi suatu produk yang ditawarkan sektor UMKM terutama cluster atau jenis usaha makanan di Kota Medan.

Konsumen, yakni para pecinta kuliner di Kota Medan merupakan titik sentral dalam konsep pemasaran mutakhir di abad 21 ini. Analisis terhadap aspek-aspek konsumen untuk mengembangkan strategi pemasaran juga mempertahankan dan bahkan mengembangkan keberadaan UMKM dengan produk makanan saat ini diharapkan mampu memenangkan dan meraih loyalitas pelanggan. Langkah tersebut harus dilaksanakan dua pihak, produsen juga hendaknya memahami keinginan dan kebutuhan konsumen. Tentu keadaan saling sepemahaman terhadap sektor ini akan menuntun produsen dan konsumen pada pilihan-pilihan dari keinginan dan kebutuhan mereka. Terutama dalam bidang penyediaan makanan di Kota Medan, sebagai pilihan konsumsi baik, rapi dan juga memiliki harga terjangkau. Menjadi sektor wiraswasta secara kompetitif, menjadi produk unggulan yang tepat dan efisien.

Di Kota Medan terdapat 1.402 UMKM Binaan Dinas Koperasi dan UKM (Dinas Koperasi dan UKM Kota Medan, 2020), pelaku Usaha Kecil Mikro sebanyak 1.279 unit, usaha kecil 112 dan usaha menengah sebanyak 11 unit. Pelaksanaan pendataan dan juga pembinaan terus dilakukan terutama agar mampu melaksanakan alih teknologi 
pemasaran produk-produk UKM Kota Medan dengan menggunakan web site.

Pembatasan Sosial Berskala Besar (PSBB) di masa pendemi covid-19 membuat perubahan strategi penjualan dan produk di sektor UMKM. Adaptasi terhadap kebutuhan masyarakat dengan menjadi penyedia makanan beku dan kue-kue. Digambarkan dalam tabel berikut:

Tabel 1.1. Peralihan Jenis Usaha UMKM di Masa Pendemi Covid 19

\begin{tabular}{ll}
\hline Jenis Produk & Persentase (\%) \\
\hline Beralih menjual makanan & 33,1 \\
Beralih menjual berbagai jenis kue & 17,1 \\
\hline Total & 50,2 \\
\hline \multicolumn{2}{c}{ Sumber: (https://ekonomi.bisnis.com/diakses pada 22 September 2020) }
\end{tabular}

Peralihan usaha dilakukan UMKM agar tetap beroperasi dengan peraturan PSBB. Perubahan jenis produk yang dijual, sebesar 50,2 persen dilakukan pengusaha, tujuannya untuk beradaptasi di tengah pandemi yang masih terus terjadi (https://ekonomi.bisnis.com/diakses pada 22 September 2020). Penjualan dilakukan dengan menggunakan jasa online sebagai strategi untuk menjaga jarak sebagai salah satu protokol kesehatan yang harus dipatuhi.

\section{METODE PENELITIAN}

Dalam penelitian ini menggunakan metodologi penelitian deskriptif kualitatif. Riset kualitatif disebut juga dengan riset yang fokus pada fenomena atau gejala yang bersifat alami. Riset ini disebut juga dengan naturalistic inquiry, field study atau studi observasional (Ali, 2014). Riset kualitatif dilakukan di daerah penelitian, sebagai field study, dari sifatnya riset kualitatif merupakan riset deskriptif. Filosofi fenomenologi disebut juga filosofi interpretivisme (Lubis, dkk, 2018).

Penelitian fenomenologi memberikan kesempatan kepada peneliti melakukan penafsiran terhadap apa-apa yang ditemukan dalam proses berlangsung. Menjadi satu bangunan sosial utuh bagi peneliti untuk dijadikan bagian temuan penelitian serta ditafsirkan secara subyektif untuk kemudian disepakati dengan informan penelitian sehingga menjadi penelitian yang dipertanggungjawabkan.

Analisis pemasaran sebagai konteks, atau fenomena yang terjadi dalam dan selama proses berlangsung. Peneliti pemberi makna dari strategi pemasaran yang dilakukan oleh Dinas Koperasi Kota Medan dalam membina usaha kecil menengah. Peneliti menjadi observan dan juga akan melakukan wawancara dengan informan-informan yang dianggap memahami dan memiliki kemampuan mendeskripsikan pengambilan keputusan dalam pelaksanaan strategi pemasaran. Interaksi antara peneliti dan informan menjadi bagian penting dalam menghasilkan laporan penelitian nantinya dala bentuk tesis.

Observasi dan wawancara mendalam akan digunakan sebagai sumber data. Dimana hasil wawancara menjadi data primer sedangkan hasil observasi peneliti akan digunakan sebagai data skunder. Bentukbentuk pertanyaan dalam teknik wawancara dalam bentuk: 1) Pertanyaan yang berkaitan dengan pengalaman dan perilaku, 2) Pertanyaan yang berkaitan dengan pendapat, 3) Pertanyaan berkaitan dengan perasaan., 4) Pertanyaan berkaitan dengan pengetahuan, 4) Pertanyaan yang berkaitan dengan indera, dan 5) Pertanyaan yang berkenaan dengan latar belakang.

\section{HASIL DAN PEMBAHASAN}

Efektivitas Efektivitas E-Marketing Dinas Koperasi dan UKM Kota Medan Terhadap UKM Binaan Di Tengah Pandemi Covid-19 Tahun 2020

Efektivitas kelompok ditentukan pada karakteristik struktural satu kelompok, terdiri dari ukuran kelompok, susunan anggota, struktur, status dan jalur-jalur komunikasi dalam kelompok tersebut (Krech, Cruthfield dan Ballachey, dalam Danim, 2004). Dengan demikian, efektivitas kelompok, merupakan fungsi khusus dari ciri-ciri satu kelompok yang membedakan satu dengan lainnya. Pertanyaan tentang ini berkenaan dengan "mana yang lebih efektif, kelompok besar atau kelompok kecil?"

Studi Kochler (1972) menjawab bahwa perluasan atau penambahan anggota, mungkin saja meningkatkan penampilan kelompok 
secara keseluruhan, akan tetapi, dapat pula mengurangi produktivitas masing-masing anggota kelompok tersebut. Peningkatan produktivitas kelompok tidak berbanding lurus dengan penambahan anggota kelompok. Hal ini sekaligus memperkuat pernyataan dan kenyataan bahwa sesungguhnya capaian efek positif dari satu kelompok dalam hal ini pengorganisasian UMKM binaan Dinas Koperasi UKM Kota Medan, didasarkan pada karakteristik atau ciri khas yang bisa dikembangkan guna mencapai ukuran, susunan anggota, struktur ideal, hingga status dan jalurjalur komunikasi tertentu untuk mencapainya.

Teori ini akan digunakan dalam melihat efektivitas strategi e-marketing Dinas Koperasi dan UKM Kota Medan terhadap UKM binaan di tengah pandemic covid-19 tahun 2020 bagi UKM pada produk makanan.

Pembagian kelompok usaha bertujuan agar memudahkan dalam mengawasi sekaligus melakukan kunjungan berdasarkan pada nama, alamat dan juga jenis usaha yang dilakukan. Penelitian terdahulu juga menunjukkan bahwa dalam kelompok kecil yang terdiri dari 4 sampai dengan 22 anggota di dalamnya, ratarata memiliki tingkat kohesifitas atau tingkat hubungan keakraban yang lebih baik untuk saling mendukung dan memberikan semangat. Juga jangkauan kekerabatan dan perasaan saling senasib terbangun dengan baik. Akan tetapi keadaan ini belum dilaksanakan, karena memang masih dalam persiapan untuk melihat perkembangan usaha kecil dan menengah yang masih terus disesuaikan dengan keadaan pembatasan sosial saat ini ditengah masa pandemi virus covid-19.

Hal ini berdasarkan pada hasil penelitian Searchore (1952, dalam Danim, 2004). Mann dan Baumgatel (1954, dalam Danim, 2004) menyatakan dalam penelitian keduanya, bahwa ada kecenderungan ketidakpuasan disebabkan karena hubungan renggang di dalam kelompok. Ketidakhadiran tanpa alasan merupakan salah satu tanda rendahnya atau mundurnya kohesifitas.

Dua penelitian ini sekaligus memperkuat kenyataan bahwa sejak dahulu sampai saat ini kebutuhan untuk keakraban hubungan dalam kelompok, unit kerja atau juga kumpulan manusia dengan tujuan bersama semakin akrab dalam kelompok kecil. Kebahagiaan akan lebih bisa dirasakan dalam kelompok kecil, sebab tidak ada dominasi orang atau individu tertentu, tidak ada jarak partisipasi aktif, komunikasi menyebar dengan kesempaan menyampaikan ide pada masing-masing orang dan pada setiap kesempatan pertemuan tatap muka atau bahkan pada masa pandemi covid 19 saat ini.

Tidak bisa juga diabaikan bahwa semakin kecil dan semakin sedikit jumlah orang dalam satu kelompok akan berdampak pada meningkatnya nilai-nilai kritis terhadap ide-ide yang disampaikan oleh anggota-anggota yang lebih dominan. Kreativitas tidak akan tertahan sebab masing-masing individu di dalam kelompok akan memberikan ide dan implementasinya.

Dengan demikian, langkah-langkah strategis yang dilakukan Dinas Koperasi dan UKM Kota Medan melalui pengelompokan usaha-usaha binaan sudah sesuai dengan tujuan capaian yang diinginkan. Diperkuat dengan penelitian-penelitian terdahulu, menunjukkan keefektifan dalam rencana, dan implementasi mempertahankan usaha di masa pandemi covid-19 bahkan meningkatkan usaha dilakukan dengan berkoordinasi dalam kelompok kecil, dengan kedekatan dan keakraban hubungan bagi masing-masing pengusaha sehingga terbangun dorongan kuat dalam diri dan kelompok untuk sukses bersama-sama dan bangkit kembali dalam usaha yang dijalankan.

Faktor penentu efektivitas kelompok, termasuk bagi UKM binaan Dinas Koperasi dan UKM Kota Medan, ditentukan juga oleh faktor: 1) Karakteristik-karakteristik perseorangan yang ada dalam kelompok, dan 2) Perpaduan atau pola kepribadian yang stabil dan menetap dalam diri setiap anggota kelompok. Artinya, sejak awal memang harus ditanamkan pesan, bahwa kelompok ini dibentuk dan diarahkan untuk kepentingan bersama, sehingga masingmasing individu sebagai anggota kelompok binaan akan mampu memainkan peran positif dan memberikan dorongan diri terbaik untuk capaian optimal dalam program-program yang sudah direncanakan bersama. Perilaku kerja sama, efisiensi, dan saling pengertian menjadi motivasi baik dengan kelancaran kerja dan produktivitas kelompok. Hal ini juga akan menjadi penekan perangai individual yang agresif, terlalu percaya diri sendiri, mengecilkan inisiatif yang lain, minat pada pemecahan masalah secara bersama-sama, 
serta bersifat bersahabat akan meningkatkan kohesifitas dalam kelompok.

Fokus pengembangan kewirausahaan dan keunggulan kompetitif usaha kecil menengah (UKM) binaan Dinas Koperasi dan UKM Kota Medan dalam usaha kuliner, di tahun 2020 , tercatat 764 usaha binaan untuk bidang kuliner (Dinas Koperasi dan UKM Kota Medan, Tahun 2020). Salah satu makanan yang menjadi oleh-oleh khas Kota Medan adalah pancek durian. Produksi makanan berbahan utama durian seperti yang dikembangkan oleh Pancake Qoqora, Radja Pancake Durian dan UKM Bolu Gulung, Brownies Kukus, Puding dan Cokelat.

Upaya meningkatkan partisipasi aktif dari para UKM binaan seperti yang, dilaksanakan dengan keaktifan mengajak pelaku UKM binaan untuk mengikuti ragam kegiatan pameran. Hal ini dilakukan untuk menjadi contoh sekaligus diharapkan mampu membangun motivasi positif yang diharapkan menjadi semangat kompetisi dengan keterangan-keterangan terhadap produk dan persyaratan yang harus dipenuhi oleh UMKM binaan Dinas Koperasi UKM yang selama ini menjadi mitra Dinas Koperasi UKM Kota Medan.

Pemenuhan perizinan, akan menjadi syarat mutlak yang harus dipenuhi guna menjadi peserta promosi UKM lokal. Dilaksanakan melalui keikutsertaan promosi KUKM Kota Medan, dalam kegiatan Pekan Raya Sumatera Utara (PRSU), Musabaqah Tilawatil Qur'an (MTQ), hari keagamaan, hari besar dan hari tertentu lainnya. Selain itu UKM binaan dengan kategori produk unggulan secara nasional juga diseleksi, merupakan upaya aktif yang dilakukan Dinas Koperasi UKM Kota Medan melalui kegiatan promosi produk unggulan yang dilaksanakan dua kali di tahun 2018, melalui event Asosiasi Pemerintah Kota Seluruh Indonesia (Apeksi) juga melalui kegiatan Hari Koperasi Nasional (Harkopnas). Kegiatan pameran di Jakarta Internasional Convention Center (JICC) juga menjadi kegiatan yang diupayakan guna mengaktifkan keikutsertaan pelaku UKM binaan di Kota Medan.

Kategori atau penilaian terhadap produk unggulan yang berhak ikut serta dan diikutkan dalam event tingkat nasional bahkan internasional menjadi motivasi tersendiri bagi UKM lainnya untuk terus meningkatkan kualitas produk, kemasan, harga dan juga memperbaiki gerai online mereka. Pengalaman menjadi salah satu penilaian penting tentang pengembangan usaha dan kualitas produk yang dihasilkan, ketersediaan bahan baku, kemampuan menyediakan modal kerja, serta keterjangkauan harga produk menjadi hal yang harus diperhatikan dalam menilai produk unggulan.

Khusus produk makanan, terutama pancake, jenis usaha ini menjadi salah satu komoditi unggulan yang biasanya dibawah dalam ragam pameran mulai dari tingkat lokal sampai pada tingkat kegiatan nasional. Selain itu juga produk seperti kue kering aneka macam dengan kripik-kripik dibawa serta juga berdasarkan pada pemenuhan persyaratan yang sudah dipenuhi oleh UKM itu sendiri. Diakui bahwa salah satu masalah yang penting diselesaikan melalui binaan Dinas Koperasi UKM Kota Medan kepada para pengusaha UKM tentang persyaratan administratif agar memiliki izin yang dibutuhkan.

\section{Implementasi E-Marketing Dinas Koperasi dan UKM Kota Medan Terhadap UKM Binaan Di Tengah Pandemi Covid-19 Tahun 2020}

Implementasi E-Marketing produk UKM binaan pada Dinas Koperasi UKM Kota Medan ditengah pandemi Covid-19 2020 dilakukan sebagai jalan keluar pemasaran modern bagi UKM Kota Medan. Sasaran strategis yang ingin dicapai menjadikan UKM tetap eksis ditengah upaya pembatasan kegiatan dan kerumunan masyarakat. Hingga mampu mengembangkan kewirausahaan dengan keunggulan kompetitif. Implementasi E-Marketing Dinas Koperasi dan UKM Kota Medan dapat digambarkan sebagai berikut:

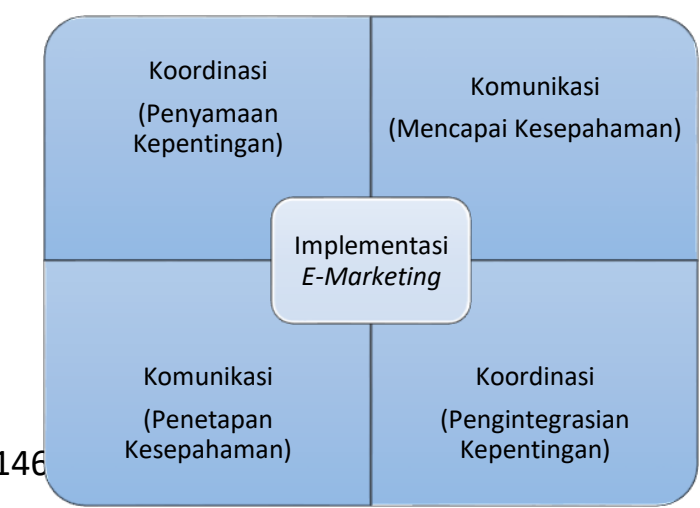




\section{Gambar 1. Implementasi E-Marketing Dinas Koperasi UKM Kota Medan}

Kebijakan, atau pilihan yang sudah ditetapkan oleh Dinas Koperasi UKM Kota Medan tehadap perubahan metode pemasaran UKM binaan di Kota Medan dilakukan dengan baik. Hal ini dilakukan melalui komunikasi dan koordinasi dengan berbagai pihak guna mencapai hasil program optimal. Komunikasi yang baik antara pembuat kebijakan dan pelaku UKM sangatlah penting. Komunikasi pemasaran menempatkan kebijakan dengan pihak target kebijakan menjadi satu paduan yang tidak terpisahkan.

Penting untuk dikoordinasikan sejak awal bahwa pelaku UKM, para pengusaha dengan berbagai macam produk makanan dan minuman yang dihasilkan sebagai binaan Dinas Koperasi UKM Kota Medan bukan merupakan pribadi atau usaha yang pasif, hanya menerima begitu saja berbagai informasi dan pesan yang disampaikan kepadanya. Komunikasi interaktif dikedepankan oleh Dinas Koperasi UKM Kota Medan untuk mendorong kreatifitas juga inovasi yang dibutuhkan untuk mengembangkan usaha dan juga mencapai nilai keunggulan kompetitif.

Strategi komunikasi bisnis efektif merupakan kebutuhan yang tidak bisa dielakkan ditengah kondisi persaingan mulai dari tingkat lokal dan nasional. Rendahnya skill, kemampuan pelaku UKM binaan untuk menciptakan produk kompetitif dan menguntungkan tentu tidak terjadi dengan sendirinya. Butuh pelatihan guna memperkuat produk dan juga pemahaman produk yang diinginkan pasar.

Penyaluran informasi yang tepat sangat diperlukan untuk meminimalkan miscommunication antara pembuat, pelaksana dan sasaran dari kebijakan. Dalam wawancara yang peneliti lakukan untuk mengetahui variable ini, ada beberapa pertanyaan yang peneliti ajukan kepada beberapa informan. Secara internal, para informan mengakui bahwa sering sekali terjadi miss komunikasi antara staff Dinas Koperasi UKM Kota Medan dengan para pelaku UKM yang meminta kejelasan waktu pelaksanaan pelatihan dan persyaratan yang harus dipenuhi. Alur yang jelas mengenai proses koordinasi sudah dimiliki namun pelaksanaannya masih kurang optimal di lapangan.

Koordinasi dimaksudkan sebagai upaya aktif Dinas Koperasi UKM Kota Medan untuk menyamakan pandangan dan juga tujuan terhadap program-program pelatihan UKM binaan. Baik dengan bidang-bidang dan bagianbagian secara internal di dalam dinas bahkan kepada pihak lain seperti bekerja sama dengan Tokopedia untuk penjualan online, Grab Indonesia untuk pesan antar makanan produk UKM, Universitas Panca Budi dalam pembinaan UKM, Badan Pengawas Obat dan Makanan (BPOM), Majelis Ulama Indonesia (MUI) Sumut tentang sertifikat halal, dan juga melakukan Rapat Dengar Pendapat (RDP) dengan Dewan Perwakilan Daerah (DPRD) Kota Medan, yakni di komisi III.

Komunikasi kunci mencapai koordinasi yang efektif. Tidak hanya menggantungkan pada hirarki manajerial, berdasarkan rencana dan tujuan kegiatan serta aturan-aturan. Koordinasi dilakukan dengan pembagian secara langsung informasi, hal-hal berkenaan dengan kepastian tugas yang harus dilakukan masing-masing bagian terpisah dalam capaian tujuan. Maka tidak boleh diabaikan bahwa, koordinasi dilakukan secara efektif bila proses informasi mulai dari perolehan dan penyebaran dilaksanakan dengan benar. Tidak melakukan manipulasi informasi untuk pihakpihak yang bermitra atau bagian-bagian di dalam organisasi itu sendiri.

Komunikasi merupakan kunci koordinasi efektif. Penyatuan tujuan-tujuan bersama secara langsung terkait langsung dengan perolehan, penyebaran dan pemrosesan informasi. Pemerintah Kota Medan, melalui tugas, fungsi dan wawenang Dinas Koperasi dan UKM, melaksanakan komunikasi secara zoom meeting terhadap pelaku UKM, sambil mendapat arahan dari Gubernur Provinsi Sumatera Utara Bapak Edy Rahmayadi. Tujuannya untuk memastikan informasi terbagi dan tersampaikan dengan benar. Semakin besar kepastian informasi tentang tugas yang dikoordinasikan, maka informasi akan mudah diarahkan guna mencapai tujuan bersama.

Masalah permodalan menjadi salah satu upaya aktif yang dicarikan jalan keluar oleh Dinas Koperasi dan UKM Kota Medan, melalui koordinasi dengan BRI. Kredit Usaha Rakyat (KUR) nantinya melalui rekomendasi layak 
atau tidak layak yang dikeluarkan oleh Dinas Koperasi dan UKM Kota Medan.

Faktor Pendukung Strategi E-Marketing Dinas Koperasi dan UKM Kota Medan Terhadap UKM Binaan Di Tengah Pandemi Covid-19 Tahun 2020

Faktor pendukung strategi E-Marketing sebagai salah satu sasaran strategis peningkatan pengembangan kewirausahaan terutama untuk mencapai keunggulan kompetitif UKM pada bidang makanan dengan potensi pengembangan produk unggul dan kompetitif ditandai dengan kuatnya dorongan pelaku UKM dan keaktifan dalam mencari informasi yang mereka butuhkan selama ini melalui dinas. Berdasarkan indikator kinerja yang ditetapkan oleh Dinas Koperasi UKM Kota Medan tahun 2020, program sosialisasi pemasaran produk melalui pasar modern dan E-Commerce, diberikan kepada 140 orang pedagang binaan Dinas Kopeasi dan UKM Kota Medan. Tentu jumlah ini tidak sesuai dengan kebutuhan dari keseluruhan jumlah UKM yang saat ini tercatat atau bahkan tidak tercatat sama sekali dalam upaya membuat data usaha satu nama, alamat, serta jenis produk yang dihasilkan sebagai bagian tanggung jawab pemerintah Kota Medan dalam hal ini menjadi tugas dan fungsi Dina Koperasi UKM. Akan tertapi, dari penjelasan tentang perizinan, dan hal lain berhubungan dengan kualifikasi produk, terbangun kesamaan pandangan tentang pentingnya meningkatkan produk, baik melalui produk unggulan, harga yang bersaing, kemasan menarik dan juga tempat pemasaran modern. Penekanan pada kepentingan bersama terus dikomunikasikan dengan para pelaku UKM hingga sampai pada pemahaman terhadap pelatihan yang dilaksanakan selama ini.

Jumlah UKM yang ikut pelatihan tentu jauh dari jumlah yang terdata saat ini terutama pada sektor makanan sebagai fokus penelitian. Akan tetapi sejak awal sudah disebutkan program E-Marketing, dilaksanakan sebagai strategi pemasaran UKM Kota Medan dalam jangka pendek pada tahun 2020, berfungsi sebagai pengungkit (leverage) guna mendukung capaian jangka panjang sebagai program keberlanjutan (sustainability) pemasaran produk-produk Koperasi dan UKM Kota Medan di market place nasional. Sasaran jangka pendek ini juga berkenaan dengan meningkatkan jumlah koperasi dan pelaku UKM yang memasarkan produknya secara online sebesar $25 \%$ dari jumlah Koperasi dan UKM Kota Medan.

Jika dilihat pelatihan yang dilaksanakan oleh Dinas Koperasi UKM Kota Medan tahun 2020 terutama untuk sektor makanan setidaknya menunjukkan upaya serius yang ingin dicapai dalam rangka meningkatkan produktivitas, pemenuhan standar daya saing, dan juga risiko kecelakaan kerja. Penerimaan secara positif dari laporan kinerja Dinas Koperasi UKM Kota Medan tahun 2020.

Kondisi kuatnya dorongan bagi para pelaku UKM binaan Dinas Koperasi Kota Medan merupakan sumber sosial yang baik untuk selanjutnya mampu dijadikan sebagai pengembangan rencana kerja tahunan dinas. Implikasi atau dampak yang dominan dari tingginya minat pelaku Koperasi UKM untuk mengikuti pelatihan, untuk mendapatkan akses permodalan, meningkatkan penggunaan teknologi yang relatif sederhana menjadi lebih modern sehingga produk yang dihasilkan dapat bersaing.

Konsep pemasaran mutakhir, atau disebut dalam penelitian ini sebagai konsep pemasaran modern ditengah kondisi pandemi Covid-19 yang terjadi di Kota Medan juga berimbas pada sektor UKM. Kepatuhan terhadap protokol kesehatan dan juga kelesuan ekonomi tidak mematikan harapan para pelaku usaha UKM untuk bertahan dan mengembangkan produk dengan daya saing tinggi. Hal ini seperti yang diucapkan oleh Kepala Dinas Koperasi Kota Medan.

\section{Faktor Penghambat Strategi E-Marketing Dinas Koperasi dan UKM Kota Medan Terhadap UKM Binaan Di Tengah Pandemi Covid-19 Tahun 2020}

Kata penghambat dalam Kamus Besar Bahasa Indonesia diterjemahkan sebagai hal, keadaan atau penyebab lain yang menghambat (merintangi, menahan, menghalangi). Sedangkan pengertian dari hambatan adalah sesuatu yang dapat menghalangi kemajuan atau pencapaian suatu hal. Pada penelitian ini faktor penghambat proses peningkatan 
pengembangan kewirausahaan dan keunggulan kompetitif UKM binaan Dinas Koperasi Kota Medan dapat diklasifikasikan menjadi dua bagian besar, secara internal dan secara eksternal.

Keterbatasan anggaran untuk melakukan promosi ternyata menjadi satu masalah internal yang sedang dihadapi dinas saat ini. Refocusing juga menjadi bagian yang tidak dapat dielakkan tidak membatalkan keseluruhan rencana promosi dengan membawa produk UKM binaan Kota Medan, paling tidak menunda atau meninjau kembali kegiatan-kegiatan yang dianggap tidak lagi relevan atau tidak dalam koridor prioritas seperti perjalanan dinas dan kegiatan lainnya yang tidak dapat dilakukan pada periode darurat untuk direalokasi.
Realokasi anggaran promosi dituangkan menjadi kegiatan Dinas Koperasi UKM Kota Medan tahun 2020, terdiri dari pengadaan, peningkatan kreatifitas, perlombaan. temu konsultasi. Kondisi ini terkait dengan pergeseran anggaran promosi yang diperuntukkan untuk penanganan kesehatan masyarakat Kota Medan, di masa pandemi Covid-19. Keadaan yang harus diterima oleh Dinas Koperasi UKM Kota Medan dengan melalukan penyesuaian-penyesuaian anggaran untuk rencana-rencana yang penting pada pelaksanaan di tahun 2020. Dampaknya, pergeseran-pergeseran anggaran disesuaikan dengan keadaan dan kondisi keuangan yang dimiliki ditandai dengan penyesuaianpenyesuaian kegiatan untuk pembinaan UKM di Kota Medan. Berikut penjelasannya pada tabel 1:

Tabel 1. Implementasi Rencana Kerja Dinas Koperasi UKM Kota Medan Tahun 2020

\begin{tabular}{clc}
\hline No & \multicolumn{1}{c}{ Kegiatan } & Keterangan \\
\hline 1. & Pengadaan Bantuan Peralatan bagi Pelaku UKM & Terlaksana \\
\hline 2 & Peningkatan Kreatifitas Bagi Ibu-Ibu dan Karang Taruna & Terlaksana \\
\hline 3 & Perlombaan dan Penilaian UP2K & Terlaksana \\
\hline 4 & Temu Konsultasi Pelaksanaan Bimbingan Administrasi dan Perizinan bagi UMKM & Terlaksana \\
\hline 5 & $\begin{array}{l}\text { Publikasi dan Promosi KUMKM Kota Medan (PRSU, MTQ, Hari Keagamaan, Hari } \\
\text { Besar dan Hari Tertentu Lainnya) }\end{array}$ & Terlaksana \\
\hline 6 & Promosi Produk Unggulan KUKM Melalui Event APEKSI dan HARKOPNAS & Terlaksana \\
\hline 7 & Penyelenggaraan Gelar Produk UMKM Kota Medan & Terlaksana \\
\hline 8 & $\begin{array}{l}\text { Fasilitasi Pembinaan Pemasaran Produk Koperasi \& UMKM di Era Ekonomi } \\
\text { Digital }\end{array}$ & Terlaksana \\
\hline & & \\
\hline
\end{tabular}

Hambatan eksternal atau faktor UKM binaan untuk memerhatikan dan tantangan juga dihadapi oleh Dinas Kopeasi mematuhi konsep pemasaran modern melalui UKM Kota Medan terutama dalam meyakinkan program E-Marketing yang dilaksanakan. dan membangun motivasi positif bagi para

Tabel 2. Perubahan Paradigma Strategi Promosi Menggunakan E-Marketing

\begin{tabular}{ccc}
\hline Faktor Promosi & Dahulu (Tradisional) & Sekarang (Modern) \\
\hline Target Audience & Masal & User \\
Frekuensi Pembelian & Sekali & Berulang \\
Saluran Distribusi & Diler & Langsung \\
R \& D & Innovation & Joint venture \\
Differentiate by & Technology & Brand \\
Driving Force & Engineering & Customer needs \\
Orientasi Perusahaan & Manufacturing/Engineering & Brand marketing \\
Public Relation $(P R)$ & Mengarahkan & Membina relationship \\
Komunikasi & Satu arah & Dua arah \\
Perilaku Konsumen & Social pressure & Individualistic \\
Kualitas & Stayling, short life & Real quality, long life \\
Geografhic scope & National & Local and segmented \\
Jenis komunikasi & Verbal & Visual \\
Tingkat persaingan & Moderate & Aggressive
\end{tabular}


Production run

Simple

Complex dan customized

\begin{tabular}{ccc} 
Jenis Media Komunikasi & Dominasi TV dan koran & $\begin{array}{c}\text { Multimedia, Integrated Marketing } \\
\text { Communication }\end{array}$ \\
Appeal & Features dan benefits & Symbols, metaphors, dan karakter \\
\hline
\end{tabular}

Sumber: Rangkuti, Freddy (2009)

Bisnis online melalui pemasaran modern produk UKM yang dilakukan Dinas Koperasi UKM Kota Medan, menjadikan teknologi sebagai perantara untuk mendapatkan produk, layanan, dan informasi pemasaran terintegrasi dengan pendekatan komunikasi pemasaran modern. Pesan dua arah di dalam pemasaran modern, menempatkan pelanggan sebagai kunci suksesnya satu produk. Tanggapan, dan bahkan kritik terhadap produk yang bersumber dari pelanggan harus dengan sungguh-sungguh diperhatikan. Promosi menjadi bagian penting untuk membangun kepercayaan terhadap produk, harga dan juga tempat berbelanja online produk-produk UKM binaan Kota Medan, terutama untuk jenis makanan. Tidak ada lagi kekecewaan karena promosi yang dilakukan ternyata membuktikan kualitas produk yang diinginkan.

Strategi komunikasi melalui penggunaan promosi produk UKM Kota Medan di bawah binaan Dinas Koperasi UKM, bertujuan merubah perencanaan pemasaran yang selama ini dilakukan dengan mandiri, melalui pertemuan antara penjual dan pembeli secara langsung dengan masih berdampaknya pandemi Covid-19 harus mematuhi protokol kesehatan salah satunya tidak menimbulkan kerumunan karena transaksi jual beli.

Strategi promosi, atau cara-cara promosi dengan pendekatan komunikasi pemasaran memberikan kenyataan tentang pentingnya people friendly, produk dan teknologi komunikasi lebih ramah, simple dan lebih membuat hidup manusia itu mudah serta menjadi lebih produktif. Komunikasi pemasaran terintegrasi (integrated marketing communication), menempatkan promosi sebagai salah satu paduan komunikasi yang bisa dilakukan untuk mencapai pelanggan sebagai target atau sasaran yang sedang dituju.

Perlu disadari bahwa produk UKM di bawah binaan Dinas Koperasi UKM Kota Medan tidak dapat memaksakan diri menjadi pesaing langsung dengan market leader. Cara terbaik yang dapat dikembangkan melalui konsisten berkonsentrasi pada target pasar yang sudah ditetapkan sebelumnya dalam perencanaan semula. Terus berusaha untuk menjadi dominan di pasar kecil tersebut (niches market). Esensinya, tetap fokus pada target market, pelanggan yang membutuhkan komunikasi dua arah, visualisasi produk baik, dipromosikan melalui multimedia dan komunikasi pemasaan terpadu (integrated marketing communication).

Pengurangan pajak dari $1 \%$ menjadi 0,5\% yang diberikan pemerintah kepada UKM sebenarnya upaya yang sangat baik. Produk dijual dengan harga relatif murah margin keuntungan tidak terlalu besar.

\section{SIMPULAN}

Efektivitas strategi pemasaran online berbasis internet produk UKM Binaan Dinas Koperasi Kota Medan masih kurang maksimal. Faktor penyebab dari hal itu dikarenakan keterbatasan anggaran promosi yang dimiliki oleh Dinas Koperasi UKM Kota Medan pada tahun 2020 juga dengan kebijakan refocusing. Implementasi strategi pemasaran online berbasis internet produk UKM binaan Dinas Koperasi UKM Kota Medan tahun 2020 di tengah masa pandemi covid-19 diterapkan dan patuh pada azaz koordinasi, gagasan kerja sama melalui bank BRI guna membuka kemudahan akses kredit, kerja sama dengan usaha-usaha online membangun market place digital dengan Grabfood, penyediaan market place di Bukalapak. Hambatan jarak pelatihan dan terbatasnya anggaran promosi menjadi hal yang tidak bisa diabaikan selama masa pandemi covid-19 dalam pelaksanaan pelatihan dan promosi UKM Kota Medan. Minat yang tinggi untuk mengikuti pelatihan terlihat cukup dominan.

\section{DAFTAR PUSTAKA}

Abdullah, T. \& Tantri, F. (2015). Manajemen Pemasaran. Jakarta: Raja Grafindo Persada.

Ali, M. (2014). Memahami Riset Perilaku dan Sosial. Jakarta: Bumi Aksara.

Damarwulan, L., Ramdansyah, A., \& Lutfi, L. (2021). Peningkatan Kekuatan Jejaring Wirausaha dan E-Marketing UMKM di Banten dalam menghadapi dampak Pandemic Covid-19. Journal of Education, Humaniora and Social Sciences (JEHSS), 3(3), 1113-1123. 
Ida Lindiawati, Hamdani Harahap, \& Siti Mardiana, Analisa Strategi E-Marketing Dinas Koperasi

doi:https://doi.org/10.34007/jehss.v3i3.49 5

Damarwulan, L., Ramdansyah, A., \& Lutfi, L. (2021). Peningkatan Kekuatan Jejaring Wirausaha dan E-Marketing UMKM di Banten dalam menghadapi dampak Pandemic Covid-19. Journal of Education, Humaniora and Social Sciences (JEHSS), 3(3), 1113-1123. doi:https://doi.org/10.34007/jehss.v3i3.49 5

Dinas Koperasi Sumut Sebut 679 Ribu UMKM Terdampak Covid-19 2020. 2020. https//:cnnindonesia.com/ekonomi/diakses kembali pada 22/9/2020.

Ekpose Dinas Koperasi dan UKM Kota Medan, (2020).

Iman, N. (2014), Mengenal E-Commerce; Fadila, Uni Nur. Hanim Maria Astuti. Feby Artwodini Muqtadirah. Analisis Faktor Kesuksesan ECommerce Pada UMKM (Usaha Kecil Menengah) Di Jawa Timur. Jurnal Teknik Pomits, 1(1), 1-10.

Lindiawati, I., Harahap, H., \& Mardiana, S. (2021). Analisa Strategi E-Marketing Dinas Koperasi Ukm Kota Medan Terhadap Ukm Binaan Di Tengah Pandemi Covid-19 Tahun 2020. Strukturasi: Jurnal Ilmiah Magister Administrasi Publik, 3(1), 14-29. doi:https://doi.org/10.31289/strukturasi.v3 i1.521

Lubis, Z. (2018). Panduan Pelaksanaan Penelitian Sosial. Medan: Perdana Publishing.

Septyanto, D. \& Dewanto, I.J. (2010). UMKM Dan Penggunaan E-Marketing Dalam Kegiatan Usaha Di Jawa Tengah dan Daerah Istimewa Yogyakarta. Fakultas Ekonomi, Universitas Esa Tunggal dan STMIK Raharja. Skripsi, p. $277-289$

Septyanto, D. \& Dewanto, I.J. (2016). Pengembangan Strategi E-Marketing UMKM Di Indonesia.
Fakultas Ekonomi, Universitas Esa Tunggal dan STMIK Raharja. Prosiding Seminar Nasional, Gedung Pascasarjana FEB. 17 Desember 2016.

Sianturi, R., Batubara, B., \& Angelia, N. (2021). Implementasi Program Sembako pada Masa Pandemi Covid-19 di Tingkat Kelurahan. Strukturasi: Jurnal Ilmiah Magister Administrasi Publik, 3(2), 185-191. doi:https://doi.org/10.31289/strukturasi.v3 i2.748.

Sutrisno, Neneng, Y.Y. \& Leo, A. (2018). Komparasi Teori Marketing Politik 4p Menurut Niffenegger dan 3p Menurut Adman Nursal. JPPUMA: JPPUMA: Jurnal Ilmu Pemerintahan dan Sosial Politik UMA (Journal of Governance and Political UMA), 6 (2): 106111

Taufiq, M., Rahmatunnisa, M., \& Rizkiyansyah, F. (2020). The Prosperous Justice Party of Bandung City and its Mix Strategy Marketing in the 2019 Election. JPPUMA: Jurnal Ilmu Pemerintahan dan Sosial Politik UMA (Journal of Governance and Political Social UMA), 8(2), 142-153. doi:https://doi.org/10.31289/jppuma.v8i2.3 698

Yuliani, A. (2017). Kemenkop UKM: 3,79 Juta UMKM Sudah Go Online, https://kominfo.go.id/ 17/11/2017, diakses kembali pada $5 / 8 / 2020$.

Zarkasyi, M., Zubaedah, R., \& Hilmi, I. (2021). Sosialisasi Kebijakan StimulusPerekonomian Nasional kepada UMKM terdampak Covid-19 untuk Mengurangi Resiko Kredit Macet. Journal of Education, Humaniora and Social Sciences (JEHSS), 3(3), 1031-1039. doi:https://doi.org/10.34007/jehss.v3i3.49 4 